\title{
III. Account of tbree unpublisbed Greek Coins, in Letters from the Rev. Stephen Weston, B.D. F.R.S. and F.A.S. to the Earl of Leicester, President.
}

Read Feb. 27, March 13 and 27, 1806.

TO THE EARL OF LEICESTER, PRESIDENT OF THE SOCIETY

O.F. A.NTIQUARIES.

MY LORD,

I Have the honour to present to your Lordship and the Society, for their inspection, a curious, unpublished, autonomous, small brass coin of Sala in Phrygia, in fine preservation, of excellent workmanship, and undoubted antiquity. ${ }^{a}$ The type of this coin is a bearded, and laureated head, and on the reverse a bunch of grapes with the letters $\mathrm{CA \Lambda H}$ very distinct: the $\mathrm{N} \Omega \mathrm{N}$, or termination of the word CA $\Lambda$ HN $\Omega N$, is now not visible, owing to the nun, omega, and nun, having been clipped, in order to reduce the size of the coin, that it might be set as a gem. This we know has been. sometimes the case with coins of superior workmanship. The position of Sala was upon the Mrander, between Pylaceum and Gazèna, to the north and south of it, making the boundary of Phrygia towards, Lycia: Its longitude, in Mercator's map, is from Ptolemy 60-15, and latitude, which is reckoned after its longitude, is $38-20$. It lies on the river to the west of Mount Taurus, between the Lycus and the Mrander. This Sala, in Phrygia magna, is not mentioned by Stephanus Byzantinus, Strabo, or D'Anville; and, although passed over in silence by these great names in geography, richly deserves to be recorded, were it only for its excellence in the numismatic art, in its free state, and under the government of its own laws.

Yol. XVI.

a See pl. I. fig. 1. 
PL. I.

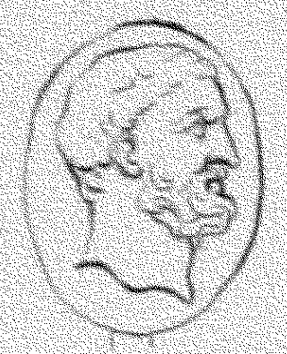

1 $P . ?$
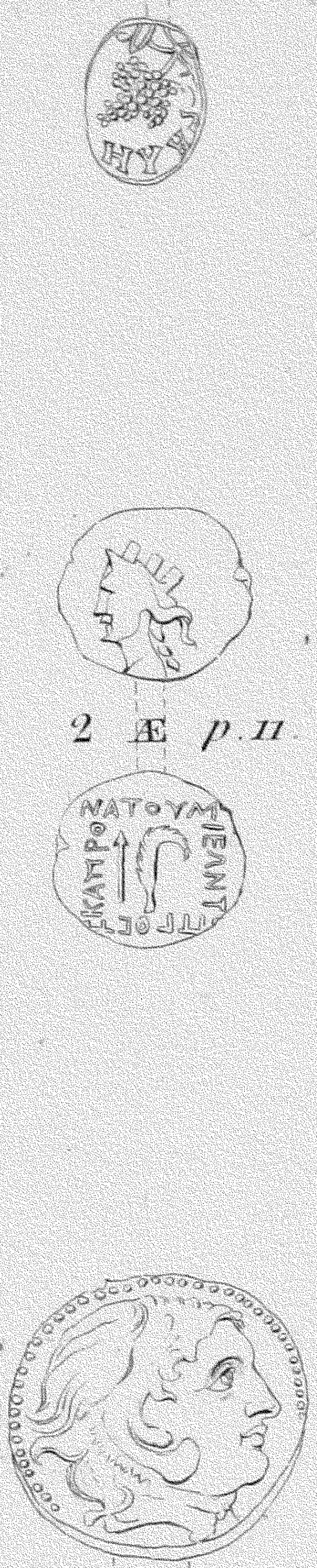

3 A: p.72.

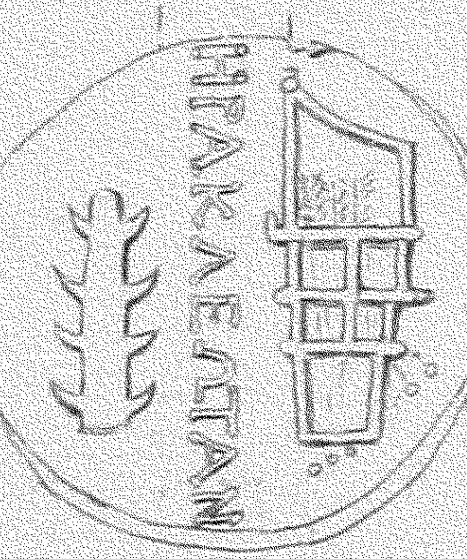

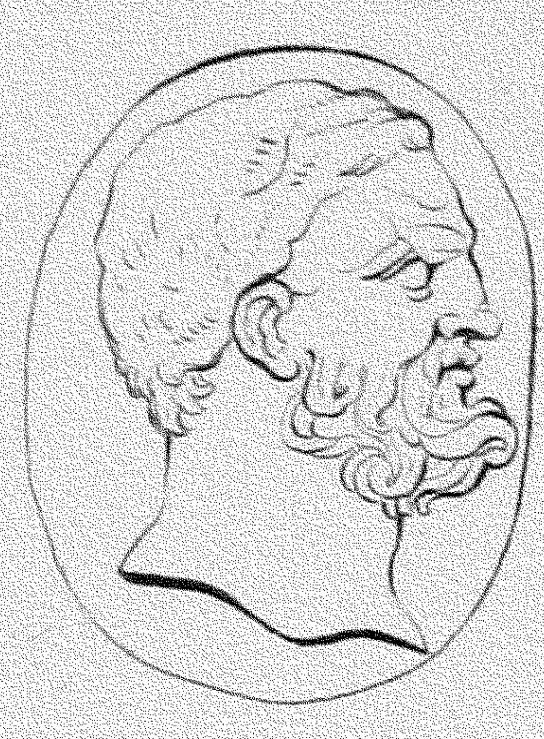

Fig. 1. enlergyed.

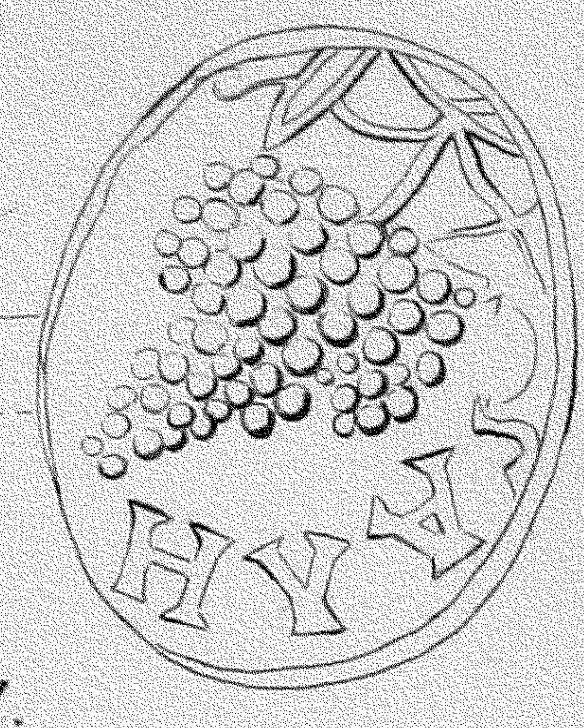

7. 135
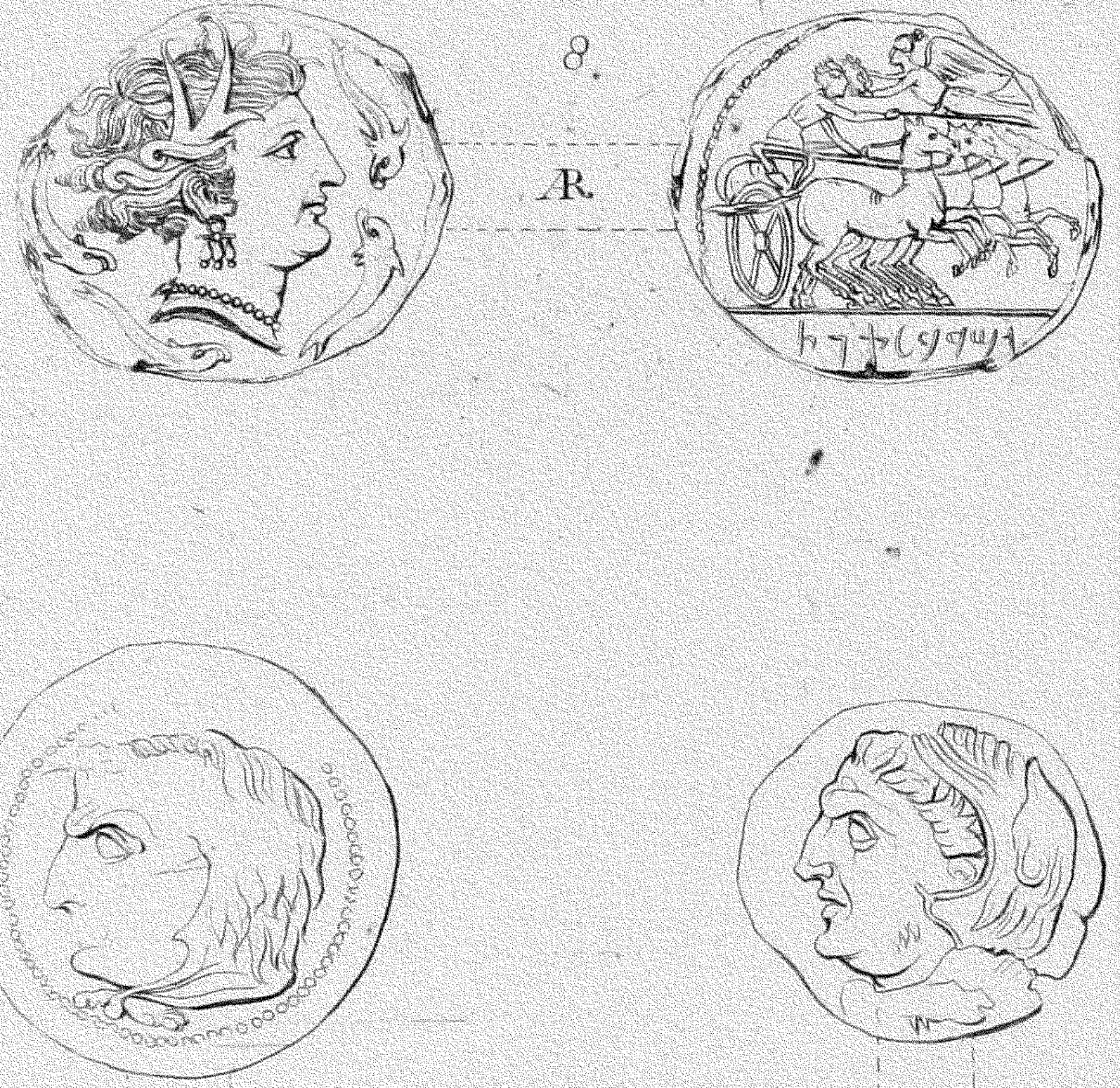

4 死 $p$

\begin{tabular}{l|ll}
5 & $\mathbf{R}$ & $p .15$.
\end{tabular}

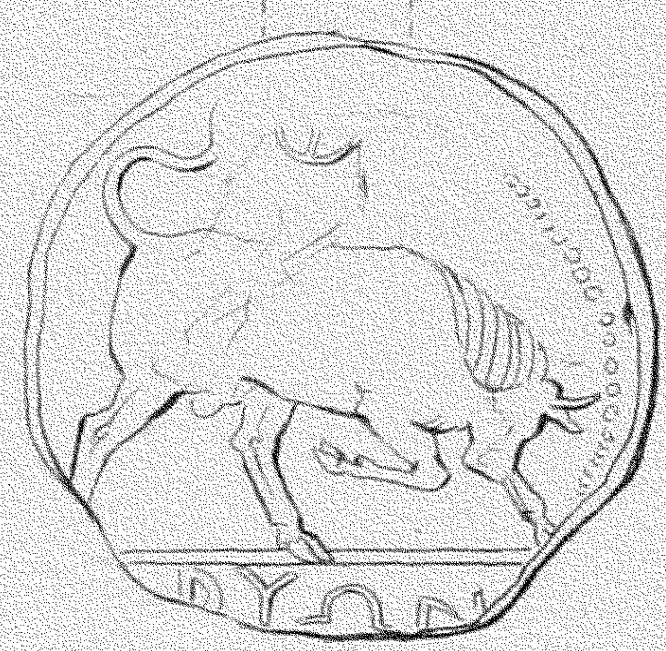


There is a coin in Pellerin with the reverse of the one before us, but with the word CA $\Lambda \mathrm{HN} \Omega \mathrm{N}$ on the head side, and a magistrate's name on the rererse; which shows the period to have been imperial, when towns were permitted to strike coins with their own magistrate's name, or name of their prefect, without the head of the reigning emperor. There are others also of the same sort in Dr. Combe, but none of them so well executed as this. The Phrygians in early times excelled in needle-work and tapestry, and had their name lengthened into Phrygiones, which came in process of time to signify $b_{:} \lambda$ ovoro $x_{i} \lambda \tau \alpha_{b}$, acupictores, designers of animals and flowers in needle-work. They excelled also in music of the graver sort; and of their skill in die-sinking, the coin I have here the honour to exhibit is no doubt among the specimens of the best times of their mint.

\author{
I have the honour, \\ My Lord, \\ To remain your Lordship's \\ Very humble Servant, \\ STEPHEN WESTON.
}

Edward-street, Portman-square,

February $27,1806$.

TO THE EARL OF LEICESTER, PRESIDENT OF THE SOCIETY

OF ANTIQUARIES.

MY LORD,

THE coin I have now the honour to present to your Lordship, and the Society, ${ }^{2}$ for the inspection of its members, is not to be found in Hunter, Haym, Pellerin, Rasche, Eckhel, or Sestini; and perhaps is the only remaining memorial of a city, not recorded by Ptolemy,

a See pl. I. fig. 2. 
Stephanus Byzantinus, or Strabo; but to console us for this extraordinary silence, we are informed by the reverse, the place it commemorates, and the river it stood upon. So much geography on a small brass coin, not half an inch in diameter, is of, rare occurrence, and remarkably singular. The inscription forms a square, inclosing two symbols, which serve to distinguish it from places of similar names, both of town and river. On the right side is a female turreted head, with something behind, in part effaced and indistinct. In the area of the reverse is an arrow and a palm-branch, and

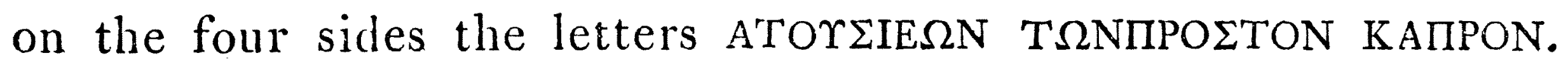
The Atusii, on the river Caper, that is, the Atusii of Assyria, on the Caper, which, with the Lycus, runs into the Tigris, just above the Gyndes. The Arrow, or Teer, in Persian, marks the rapidity of the stream; and Tekr, in Arabic, means flowing precipitately, from which latter word we get the name of Tigris; not, indeed, according to Curtius, a and Eustathius, b or Dionysius the geographer, for Curtius is wrong when he says, that the Tigris got its name because Tigris, in Persian, is an arrow; Teer, as I have shown, is an arrow in that language; but Tikr, or Tigr, in Arabic, whence the Romans made Tigris, is a rapid current. The modern name of this river is Dejleh, in Persian. The name Atusa, in Persian Atesh, and in Greek Atossa, is familiar to us from its being the appellation of the mother of Xerxes. The square form of the inscription is peculiar to the coins of Parthia and Cappadocia, and the palmbranch is the production of Assyria.

My Lord,

I have the honour to remain

Your Lordship's very humble Servant,

STEPHEN WESTON.

Edwaid-street, Portman-square, March 12, 1806.

a 2 Curt. lib. iv. c. 9, p. 25. $3 \mathrm{~d}$ edit. 4 to.

- Ad. v. 984. 
TO THE EARL OF LEICESTER, PRESIDENT OF THE SOCIETY OF $\Lambda$ NTIQUARIES.

\section{MY LORD,}

I HAVE the honour to offer to the inspection of your Lordship and the Sociaty, a coin of Heraclea, which does not appear to have been described in any numismatical author, or elsewhere in the course of my research and inquiry.

There are, it is well known, in Stephanus Byzantinus twentythree towns of the name of Heraclea, which have been given, as they have occurred on coins to different countries.

To those with the letters HPAK $\Lambda E \Omega T A N$, Acarnania has been assigned.

To those with the legend HPAK $\Lambda E A$, Bithynia has been given.

To those with HPAK $\triangle E \Omega T \Omega N$, Caria.

To those with HPAK $\Lambda$ HI $\Omega$ N and HPAK $\Lambda E I \Omega N$, Italia.

To one that terminates in $E \Omega N$, instead of the usual ending of $H I \Omega N$, with the aspirate prefixed, as thus, $-\operatorname{HPAK} \Lambda E \Omega N$, Lucania.

To those with HPAK $\Lambda$ ET $\Omega$ N HPAK $\Lambda$ E and HPAK $\Lambda E I A$, Macecionia.

Pellerin at one time gave certain coins of Heraclea, with the Doric termination to $\Lambda$ carnania; and in his Supplement removed them to Lucania; whether on good grounds, it is not so easy to decicie.

Eckhel says he was long in doubt to which of the Heracleas he should ascribe a silver coin with the legend HPAK $\Lambda E \Omega T A N$, and whether he should give it to the Heraclia of Lucania, or no, for, says he, undoubted Heraclean coins belonging to this country terminate in $\mathrm{E} \Omega \mathrm{N}$ and $H I \Omega \mathrm{N}$, with the aspirate mark ( $(-)$ prefixed, but that is no reason why it should not use the termination TAN, since the Ileracleans were originally a colony from Laconia, and to whom the Doric language was familiar, as appears from the Heraclean tables written in that dialect.

- See pl. I. fig. 3. 
The copper coin which I here exhibit, and which I have not found any where engraved, is of good workmanship, and may belong to Acarnania, or Lucania. It bears on it the head of Hercules, looking to the right, and is adorned with the spoil of the lion, and has on the reverse $\operatorname{HPAK} \Lambda E \Omega$ TAN, between the bow and arrows in their case, 'arcumque coryto,' and the club.

The Doric termination will allow us to call this coin Heraclea, in Acarnania, where Dr. Combe and Pellerin have placed others of a similar termination; or of Heraclea, in Lucania, whither Pellerin, in his Supplement, iii.p. 85, has removed them.

I have the honour to remain,

My Lord,

Your Lordship's very humble Servant, STEPHEN WESTON.

Edward-street, Portman-square,

March 25, 1806. 